At-Taradhi: Jurnal Studi Ekonomi

Volume XI Nomor 2, Desember 2020

P-ISSN: 1979-3804, E-ISSN: 2548-9941

\title{
Peran Koperasi Simpan Pinjam Pembiayaan Syariah Terhadap Usaha Mikro Kecil Menengah (Studi pada Baitul Maal wa Tamwil Nahdhatul Ulama Cabang Pasean Pamekasan)
}

\section{Moh. Romin}

Pascsarjana, Universitas Islam Negeri Sunan Ampel, Surabaya, Indonesia. E-mail: moh.romin93@gmail.com

\section{ARTICLE INFO}

Kata Kunci:
Baitul Maal Wat Tamwil;
Peran; UMKM

Cara Sitasi:
Romin, Moh. "Peran
Koperasi Simpan
Pinjam Pembiayaan
Syariah (KSPPS) BMT
NU Cabang Pasean
Pamekasan Terhadap
Usaha Mikro Kecil
Menengah (UMKM)"
At-Taradhi: Jurnal
Studi Ekonomi 11, no.
2 (2020): 120-134.

\begin{abstract}
BMU NU Pasean Pamekasan Branch in a Sharia financial institution can be said to be new in the Pamekasan area, therefore researchers are more interested in the BMU NU financing products used by UMKM, and include part of the total for business actors who are able to contribute to people who do not have jobs in Pamekasan. The purpose of this study was to see the role of BMU NU Pasean Pamekasan Branch on UMKM. The methodology used in this research is; descriptive with a qualitative approach. The data used are primary data, namely; interview results and data from BPS Pamekasan Regency as well as secondary data. Based on the results of his research, the role of BMU to UMKM in the form of UMKM financing according to BPS Pamekasan data for 2020 amounted to 108,467 UMKM, while UMKM that took financing at LKS were; at BMU NU Pasean Pamekasan Branch around 1452. This means that in the Pamekasan area only $0.01 \%$ of UMKM are customers of Islamic financial institutions, namely BMU NU Pasean Pamekasan Branch. In addition, BMU NU is also a business assistant and has also held financial management training, but this program is not effective because UMKM are not proactive.
\end{abstract}

BMT NU Cabang Pasean Pamekasan dalam lembaga keuangan Syariah bisa dikatakan baru di daerah Pamekasan, oleh karena itu peneliti lebih tertarik pada produk pembiayaannya BMT NU yang digunakan oleh UMKM, dan termasuk bagian dari keseluruhan bagi pelaku usaha yang mampu memberikan sumbangsih terhadap orang yang tidak memiliki pekerjaan di Pamekasan. Tujuan penelitian ini untuk melihat peran BMT NU Cabang Pasean Pamekasan terhadap UMKM. Metodologi yang dipakai dalam penelitian ini yaitu; deskriptif dengan pendekatan kualitatif. Adapun data yang dipakai adalah data primer yaitu; hasil wawancara dan data dari BPS Kabupaten Pamekasan serta data sekunder. Berdasarkan hasil penelitiannya, peran BMT terhadap UMKM berupa pembiayaan UMKM sesuai dengan data BPS Pamekasan tahun 2020 berjumlah 108.467 UMKM, sedangkan UMKM yang mengambil pembiayaan di LKS yaitu; di BMT NU Cabang Pasean Pamekasan sekitar1452. Dalam artian di daerah Pamekasan hanya 0,01\% UMKM yang menjadi nasabah lembaga keuangan Syariah yaitu BMT NU Cabang Pasean Pamekasan. Selain itu BMT NU juga sebagai pendamping usaha dan juga pernah mengadakan pelatihan manajemen keuangan, tapi program ini tidak efektif karena UMKM yang tidak proaktif.

\section{Pendahuluan}

Baitul Maal Wat Tamwil (BMT) memiliki 2 istilah, pertama, Baitul Maal adalah suatu lembaga keuangan umat Islam yang sumber dananya dari pendapatan infaq, sodaqoh, zakat, hibah 
dan lainnya. Kedua, Baitul Tamwil suatu lembaga keuangan, dimana dana yang diperoleh dikelola oleh umat yang berlandasan ajaran syariat Islam. BMT dan Bank Syariah memiliki kesamaan yang bergerak sama dengan bank koperasi, kecuali yang membedakan dari segi ukurannya yang kecil dan tidak mempunyai akses ke pasar uang. ${ }^{1}$ BMT yang pada awalnya hanya bersifat organisasi kemasyarakatan informal, atau komunitas lokal. Maka terbentuknya koperasi dengan konsep sudah dikenal oleh masyarakat dan bisa memberi status legal formal yang dibutuhkan. Penyebutan sebagai gerakan adalah untuk menekankan aspek idealistik BMT yang ingin memperbaiki nasib masyarakat golongan ekonomi bawah serta keterkaitannya dengan nilai-nilai Islam Akan tetapi, ada pula Faktafakta atau fenomena tumbuh dan berkembang BMT bisa disebut sebagai gerakan. ${ }^{2}$

Pada tahun 1997-1998 BMT sudah tumbuh dan berkembang sebagai bagian dari Lembaga Keuangan Mikro (LKM) di Indonesia, baik dilihat dari kinerja keuangan maupun jumlah masyarakat yang dilayani. Segala kelebihan yang dimiliki oleh LKM pun menjadi bagian BMT, salah satunya sebagaimana telah banyak diketahui para ahli ekonomi, bahwa terbukti BMT lebih tahan terhadap goncangan krisis perekonomian. ${ }^{3}$

Sumber dana BMT berasal dari masyarakat yang dikonsep dalam bentuk simpan-pinjam, dengan sistem kerja yang diambil BMT pada akhirnya sama dengan sistem kerja bank Syariah yang menjadi lembaga intermediasi. ${ }^{4}$ BMT adalah suatu lembaga keuangan yang menerapkan konsep Syariah yang menggunakan prinsip ekonomi kerakyatan dengan meningkatkan ekonomi mikro. Perkembangan BMT yang sangat cukup pesat mampu bersaing di tengah perkembangan lembaga keuangan mikro konvensional. ${ }^{5}$

Kemenkop UKM Kemkominfo melakukan kerjasama untuk program UMKM go online, dengan jumlah saat ini berkisar yang ada di Indonesia, yakni 59,2 juta. Pemerintah juga berharap dapat mempercepat transformasi UMKM di Indonesia menuju digital. ${ }^{6}$ Sedangkan untuk UMKM di daerah Pamekasan, Madura saat ini sudah ada 108.467 pelaku UMKM. ${ }^{7}$

Perkembangan sektor perbankan Syariah termasuk BMT NU Cabang Pasean Pamekasan diharapkan secara optimal dapat membantu perkembangan UMKM di daerah Pasean Pamekasan. Pemerintah saat ini, memberikan program bantuan bagi pelaku UMKM yang pada saat ini posisi yang sangat penting didalam membantu perekonomian di Indonesia

\footnotetext{
${ }^{1}$ Makhalul Ilmi, Teori Dan Praktek Lembaga Mikro Kenangan Syariah (Yogyakarta: UII Press, 2002). h.62.

${ }^{2}$ Amin Aziz, Kegigihan Sang Perintis (Jakarta: MAA Institute, 2007). h.6.

${ }^{3}$ Solikhul Hidayat, "Persepsi Masyarakat Terhadap Baitul Maal Wat Tamwil (Bmt) DalamPemberdayaan Ekonomi Masyarakat”, Al-Uqud: Journal of Islamic Economics Volume 2 Nomor 2, Juli (2018): 199.

4 “LPS Bagi BMT Sebagai Bentuk Perlindungan Hukum," Http://wmw.Academia.Edu/5380514/Urgensi. diakses tanggal 9 Juni 2020, pukul 16:44

${ }^{5}$ Novita Dewi Masyitoh, "Analisis Normatif Undang-Undang Nomor 1 Tahun 2013 Tentang Lembaga Keuangan Mikro (LKM) Atas Status Badan Hukum Dan Pengawasan Baitul Maal Wat Tamwil (BMT)," Jurnal Economica Vol.V (2014): 18.

${ }^{6}$ Teten Masduki, "Yang Sebelumnya Jumlah Pelaku Umkm Di Tahun 2018 Diprediksi Mencapai 58,97 Juta Orang,Sekarang Menggagas Program Bertajuk 8 Juta UMKM Go Online," Https:/ / www.Cnnindonesia.Com/Ekonomi/20171115161037-78-255819/Kemenkop-Ukm-379-Juta-Umkm-SudahGo. Diakses Pada 9 Agustus 2020.

7 Koran Madura, "Data Pelaku UMKM," Http://mww.Koranmadura.Com/2018/12/Ternyata-Data-PelakuUmkm-Di-Pamekasan/. Diakses Pada 9 Agustus 2020.
} 
yang lagi turun disebabkan adanya wabah virus corona. Dengan demikina, pelaku usaha UMKM diharapkan meningkatkan perekonomian nasional. Namun, masih $60 \%$ yang dapat memenuhi kebutuhan dalam mengambil pembiayaam di lembaga keuangan, disebabkan banyak yang tidak memiliki persyaratan yang diajukan oleh pihak lembaga pembiayaan UMKM tersebut. ${ }^{8}$

Berdasarkan ketidakmampuan bank untuk menjangkau UMKM tersebut, BMT seharusnya mampu hadir sebagai jalan alternatif, sebab dengan model penyaluran dananya yang simpel, cepat, dan mudah, BMT dapat dengan leluasa langsung turun ke golongan masyarakat akar rumput. Proses pembiayaan yang sederhana berikut jangkauannya hingga ke akar rumput ini membuat BMT semakin potensial untuk memberikan untuk memberikan layanan pembiayaan ataupun modal kerja jangka pendek yang sangat UMKM perlukan. ${ }^{9}$ Oleh karena itu, Kondisi dilapangan yang masih banyak praktek rintenir, maka untuk mengurangi praktek seperti itu diperlukan peran koperasi simpan pinjam pembiayaan Syariah (KSPPS) BMT NU cabang Pasean Pamekasan terhadap usaha mikro kecil menengah (UMKM), maka fokus penelitian ini berupaya untuk mendeskripsikan peran Koperasi Simpan Pinjam Pembiayaan Syariah (KSPPS) BMT NU, serta bagaimana produk pembiayaan BMT NU yang digunakan oleh UMKM yang nantinya akan melahirkan suatu lowongan pekerjaan khususnya di daerah Pamekasan Madura.

\section{Kajian Teori}

1. Teori Baitul Maal Wa Tamwil (BMT)

Baitul Maal Wa Tamwil (BMT) secara etimologi, “Baitul Maal' berarti 'rumah uang', sedangkan "Baiut Tamwil" mengandung pengertian "rumah pembiayaan". ${ }^{10}$ Maka dari itu, Baitul Maal Waa tamwil (BMT) bisa dikatakan lembaga yang memiliki dua unsur, pertama, Baitul Maal dan Baitul Tamwil. Baitul Maal lebih mengarah pada usaha-usaha non-profit, seperti, infaq, zakat dan sedekah. Kedua, Baitul Tamwil sebagai usaha pengumpulan dana dan penyaluran dana komersial. ${ }^{11}$

Baitul Maal Wa Tamwil (BMT, adalah sekumpulan bisnis yang berperan untuk menjaga harta umat, dengan memanfaatkan sumber daya manusia. BMT dalam mengembangkan usahanya melakukan konsep transpransi, mudah, cepat dan terpercaya didalam mengjaga harta umat. Oleh karena itu, BMT tidak sama dengan bank, maka BMT tidak mengikuti peraturan perbankan tersebut. ${ }^{12}$

Sesuai dengan kaidah Ushul Fiqib "مالا يتم الو اجب الابه فو اجب", artinya bahwa sesuatu yang harus ada untuk menyempurnakan yang wajib, maka ia wajib diadakan. Misalnya, dalam Mencari nafkah untuk kebutuhan keluarga atau yang lainnya adalah wajib. Pada

\footnotetext{
8 Aswandi S, "Umkm Di Tengah Krisis Ekonomi-Perannya Besar, Minim Perhatian Pemerintah," bttp:/ / mww.sme-center.com (2007). Diakses Pada 11 Agustus 2020.

${ }^{9}$ Fauzi Arif Lubis, "Peranan BMT Dalam Pemberdayaan Ekonomi Nasabah Di Kecamatan BerastagiKabanjahe Kabupaten Karo ( Studi Kasus Bmt Mitra Simalem Al-Karomah )” (n.d.).

${ }^{10}$ Jamal Lulail Yunus, Managemen Bank Syariah “Mikro (Malang: UIN Malang Press, 2009). h. 8.

${ }^{11}$ Mohamad Heykal Nurul Huda, Lembaga Kenangan Islam Tinjanan Teoritis Dan Praktis (Jakarta: PT. Fajar Interpratama Mandiri, 2013). h. 363.

${ }^{12}$ Muhammad Ridwan, Manajemen Bank Syariah (yogyakarta: UPP AMP YKPN, 2003). h. 126.
} 
zaman sekarang dalam kegiatan perekonomian tidak akan sempurna tanpa adanya lembaga perbankan, maka lembaga perbankan datang sebagai solusi untuk kemaslahatan umat, khususnya masyarakat kecil. ${ }^{13}$

BMT Sebagai lembaga bisnis yang lebih mengutamakan dalam pengembangan usaha pada sektor keuangan. Maka kehadiran lembaga tersebut sangat membantu bagi pelaka usaha UMKM dengan memberikan bantuan pinjaman kepada masyarakat dalam pengembangan usahanya atau bagi pemula, Secara umum gambaran tentang BMT adalah: ${ }^{14}$

a. Tujuan BMT, memberantas kemiskinan dengan meningkatkan sumber daya, baik dari permodalan maupun dari kemampuan pelaku usaha UMKM.

b. Sifat BMT, lembaga bisnis yang bergerak sendiri, dan dikembangkan oleh anggota maupun masyarakat.

c. Visi BMT, menjadikan lembaga keuangan mandiri, transpransi, mudah, sehat dan berkualitas, serta berada dijalan Allah SWT.

d. Misi BMT, memberantas kemiskinan, menghafus praktek rentenir, serta menjaga kesejahteraan anggonya.

e. Fungsi BMT, adalah;

1) Mengorganisir, mendorong dan mengembangkan potensi serta kemampuan ekonomi anggota, kelompok usaha anggota muamalat dan kerjanya.

2) Memberikan pelatihan dan perbaikan atau mengasah kemampuan anggota dalam meningkat bakat didalam memberikan pelayanan terhadap masyarakat.

2. Peran BMT di Masyarakat

a. BMT berkontribusi dalam penyediaan permodalan bagi UMKM yang tidak bisa mengakses kelembagaan keuangan (bank), dengan prosedur bersifat fleksibel, jemput bola dan tidak rumit serta tidak sulit. ${ }^{15}$

b. BMT harus datang sebagai solusi alternatif dalam mentiadakan praktek rentenir yang sudah menjadi kebiasaan ditengah-tengah masyarakat.

c. Tugas BMT selain menyalurkan dana kepada masyarakat, maka BMT harus istiqomah dengan menjalan prinsip-prinsip syariah. ${ }^{16}$

d. BMT harus memberikan pelatihan-pelatihan mengenai cara transaksi yang baik menurut Islam.

\footnotetext{
${ }^{13}$ Adiwarman Karim, Bank Islam Analisis Fiqib Dan Kenangan (Jakarta: RajaGrafindo Persada, 2006). h. 43.

${ }^{14}$ Andri Soemitra, Bank Dan Lembaga Keuangan Syariab (Jakarta: Kencana Prenada Media Group, 2010). h. 452.

15 Dimas Saputra, "Respons Masyarakat Terhadap Produk Pembiayaan BMT Di Kartasura” 1, no. 2 (2017).: 249 .

${ }^{16}$ Lubis, "Peranan BMT Dalam Pemberdayaan Ekonomi Nasabah Di Kecamatan Berastagi-Kabanjahe Kabupaten Karo ( Studi Kasus Bmt Mitra Simalem Al-Karomah )."
} 
e. BMT juga harus Menjaga keadilan ekonomi masyarakat, serta melakukan evaluasi dalam menjaga keberlangsungan pelaku usaha UMKM tersebut dengan memberikan arahan secara Islami. ${ }^{17}$

3. Usaha Mikro, Kecil dan Menengah (UMKM)

Pengertian UMKM yang sesuai dengan Undang-undang Nomor 20 Tahun 2008 adalah $:^{18}$

a. Usaha Mikro, adalah usaha sesorang baik perorang maupun sekelompok orang yang sesuai peraturan undang-undang.

b. Usaha Kecil, adalah usaha seseorang yang berdiri sendiri, baik perorangan atau perusahaan yang masih tidak memiliki cabang.

c. Usaha Menengah, adalah usaha seseorang yang berdiri sendiri, baik perorangan atau perusahaan yang masih tidak memiliki cabang. Usaha Kecil atau usaha besar dengan jumlah kekayaan bersih atau hasil penjualan tahunan sebagaimana diatur dalam undang-undang.

Kriteria UMKM, dinyatakan yang di atur dalam Undang-undang Nomor 20 Tahun 2008 tentang Usaha Mikro, Kecil dan Menengah (UMKM), adalah:

a. Kriteria Usaha Mikro adalah sebagai berikut:

1) Kekayaan bersih yang dimiliki paling banyak $\mathrm{Rp} 50.000 .000,00$ (lima puluh juta rupiah) tidak termasuk tanah dan bangunan tempat usaha; atau

2) Hasil penjualan tahunan yang dimiliki paling banyak Rp 300.000.000,00 (tiga ratus juta rupiah).

b. Kriteria Usaha Kecil adalah sebagai berikut:

1) Kekayaan bersih lebih dari Rp 50.000.000,00 (lima puluh juta rupiah) sampai dengan paling banyak Rp 500.000.000,00 (lima ratus juta rupiah) tidak termasuk tanah dan bangunan tempat usaha; atau

2) Memiliki hasil penjualan tahunan lebih dari Rp 300.000.000,00 (tiga ratus juta rupiah) sampai dengan paling banyak Rp 2.500.000.000,00 (dua milyar lima ratus juta rupiah).

c. Kriteria Usaha Menengah adalah sebagai berikut:

1) Memiliki kekayaan bersih yang dimiliki lebih dari Rp 500.000.000,00 (lima ratus juta rupiah) sampai dengan paling banyak Rp 10.000.000.000,00 (sepuluh milyar rupiah) tidak termasuk tanah dan bangunan tempat usaha;

2) Hasil penjualan tahunan yang dimiliki lebih dari Rp 2.500.000.000,00 (dua milyar lima ratus juta rupiah) sampai dengan paling banyak Rp 50.000.000.000,00 (lima puluh milyar rupiah).

Pada laporan perkembangan UMKM triwulan II 2019/2020, menurut klarifikasi mengenai pelaku pembiayaan, sebagian besar pembiayaan UMKM disalurkan pada

\footnotetext{
${ }^{17}$ M. Nur Rianto Al-Arif, Dasar-Dasar Ekonomi Islam (Solo: PT Era Audicitra Intermedia, 2011). h.381.

${ }^{18}$ Nomor 20. Undang-undang Tahun 2008.
} 
usaha menengah sebanyak 44,4\% dan selebihya kepada usaha kecil sebanyak 30,1\% dan usaha mikro sebanyak $25,5 \%$.

\section{Gambar 1. Klarifikasi Pelaku UMKM}

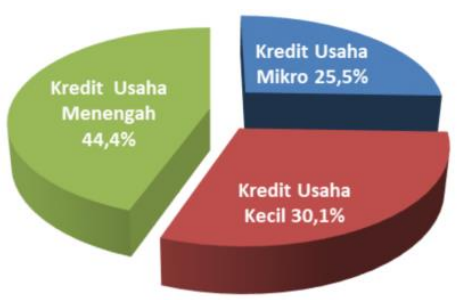

Sumber : Bank Indonesia, laporan perkembangan UMKM

Laporan perbankan, mengenai kredit UMKM yang disalurkan oleh Bank Persero sebanyak Rp 531,7 triliun(51,8\%), dan diikuti Bank Swasta Nasional Devisa sebesar Rp 318,6 triliun(31,1\%), serta BPD Rp70,4 triliun (6,9\%), BPR/BPRS Rp 51,3 triliun (5,0\%), Bank Swasta Nasional Non Devisa sebesar Rp 46.3 triliun(4,5\%), Bank Campuran Rp. 6,6 triliun (0,6\%), serta Bank Asing Rp 849,8 triliun (0,1\%).

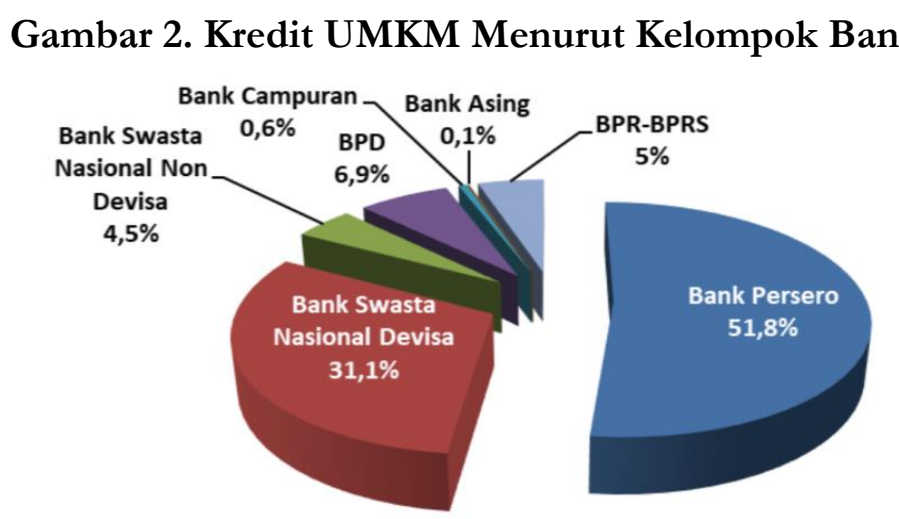

Sumber : Bank Indonesia, Laporan Perkembangan UMKM

4. Peran BMT Terhadap Usaha Mikro Kecil Menengah (UMKM)

Peran BMT dalam membantu bagi pelaku UMKM dalam memanjukan Perekonomian di daerah Pasean Pamekasan Madura dan khususnya di Indonesia, memiliki peranan yang sangat penting dalam rangka meningkatkan daya saing perekonomian secara mikro, peranan ini akan mengurangi praktek rentenir, kemiskinan, dan krisis nasional yang terjadi pada saat ini disebabkan adanya virus corona. Maka pemkab pamekasan harus benar-benar mendukung adanya lembaga keuangan seperti, lembaga BMT atau yang lainnya yang berbasis Syariah, terutama di daerah pamekasan terkenal dengan kota pendidikan atau kota pondok, oleh karena itu, dengan adanya BMT akan menjawab sebagai keuangan alternatif. ${ }^{19}$ Perhitungan bagi pelaku UMKM yang masih beroperasi sekitar 52 juta unit. Dengan demikian, maka perlu kajian ulang dalam mengembangan aset UMKM, dengan mengadakan seminar atau kajian tentang

\footnotetext{
${ }^{19}$ Braman Setyo, "Deputi Bidang Pembiayaan Kemenkop UKM," Https://Investor.Id/Business/PamekasanKabupaten-Pertama-Komit-Kembangkan-Koperasi-Syariah. diakses pada 9 Juli 2020.
} 
pengembangan ekonomi dalam memajukan usaha tersebut, baik berupa pendanaan modal usaha. ${ }^{20}$

Tingkat kesejahteraan masyarakat akan di ukur dari tingkat kemakmuran pelaku usaha UMKM, baik keberlangsungan aset usahanya, serta memakai sistem ekonomi Islam yang sudah dibekali sebelumnya oleh pihak lembaga penyaluran dana bagi pelaku usaha UMKM, dan tidak lupa BMT juga menghilangkan kebiasaan burut masyarakat yang selalu mengambil takaran lebih/mengurangi timbangan, praktek riba. ${ }^{21}$

Matnin menuturkan, saat ini, sudah ada sekitar 50 orang yang telah memiliki kompetensi sebagai pengawas di lembaga keuangan Syariah, sehingga pengembangan jenis ekonomi kedepan lebih optimal. Selain bertanggung jawab atas terbentuknya Dewan Pengawas Syariah, Puskomsa bentukan Dinas Koperasi dan Majelis Ulama Indonesia (MUI) Pamekasan juga bertugas meningkatkan sumber daya manusia (SDM) para pengurus koperasi di Pamekasan tentang sistem pelaporan keuangan berbasis teknologi. ${ }^{22}$ Oleh karena itu, pelaku usaha UMKM sangat terbantu dengan adanya program Lembaga Keuangan Syariah yang mengeluarkan misalnya; pencairan modal, training usaha bagi pemula, dan lainnya bagi pelaku usaha UMKM.

Ada tiga bentuk kerjasama antara program perbankan Syariah berserta lembaga keuangan mikro Syariah, adalah;

a. Bentuk penyaluran dana, dimana bank berwenang/memutuskan dalam pemberian modal tersebut kepada pelaku usaha UMKM.

b. Bentuk pengguliran dana, yang akan diberikan kepada pelaku usaha UMKM, dan yang berwewenang dalam memberikan keputusan adalah lembaga keuangan mikro Syariah.

c. Bentuk pembiayaan bersama antara bank Syariah dengan lembaga keuangan mikro Syariah, dimana kebijakan/wewenang berada pada kedua belah pihak. ${ }^{23}$

5. Pentingnya Kemitraan Lembaga Keuangan Syariah dan UMKM

Muhammad Yunus, seorang peraih Nobel Perdamaian, mendirikan bank khusus pembiayaan usaha kecil, lewat Grameen Bank, menurut beliau penting sekali bagi pelaku usaha UMKM melakukan kerjasama dengan lembaga penyaluran dana, karena akan terjadi timbal balik yang saling menguntungkan dari kedua belah pihak. ${ }^{24}$ Pada tahun 1997-an, telah terjadi krisis moneter. Maka yang menyelamat krisis tersebut adalah pada sektor usaha yang nyata bergerak di tengah-tengah masyarakat, seperti pertanian, perdagangan tradisional, koperasi, industri kecil, dan seterusnya. Oleh karena itu,

20 Friska Yolandha, "Pembiayaan Mikro Perbankan Syariah 70 Persen," Https:/ / wmw.Republika.Co.Id/Berita/Ekonomi/Syariah-Ekonomi/12/10/25/Mcg98q-Pembiayaan-MikroPerbankan-Syariah-70-Persen. Diakses Pada 19 Juli 2020.

${ }^{21}$ Fitriani Prastiawati et al., "Peran Pembiayaan Baitul Maal Wat Tamwil Terhadap Perkembangan Usaha Dan Peningkatan Kesejahteraan Anggotanya Dari Sektor Mikro Pedagang Pasar Tradisional” 17, no. 2 (2016): 197-208.

22 Matnin, Wawancara, Pamekasan, 15 Juli 2020.

${ }^{23}$ Ascarya, Akad \& Produk Bank Syariah (Jakarta: PT RajaGrafindo Persada, 2008). h. 34.

${ }^{24}$ Ahmad Ifham Sholihin, Ini Lho, Bank Syariah (Jakarta: Hamdalah, 2008). h.257. 
perusahaan yang besar dan yang memiliki modal besar belum tentu bisa menyelamat risiko yang terjadi seperti penurunan ekonomi, terutama di Indonesia.

Peranan terpenting dalam melakukan sebuah usaha adalah harus melakukan kerjasama karena mengingat pada tahun 1997-1999-an, pemerintah sering mengeluarkan modal yang salah sasaran, apalagi kepada pengusaha yang besar, maka jadinya yang kaya semakin kaya, yang miskin semakin miskin, sehingga risikonya beban bunga semakin besar, dan menyebabkan ketidak kesejahteraan dalam menjalan bisnisnya. ${ }^{25}$

BMT menawarkan kepada masyarakat/anggotanya dalam melakukan pembiayaan diantaranya; pembiayaan bai bitsaman ajil (BBA); pembiayaan murababab (MBA); pembiayaan mudharabah (MDA); pembiayaan musyarakah (MSA); dan pembiayaan alqardh al-hasan. ${ }^{26}$ Adapun, yang diperbolehkan bagi pelaku usaha UMKM, jika mengambil pembiayaan modal dengan penyaluran dana tersebut harus dijadikan dalam bentuk usaha dan tidak diperbolehkan dengan menggunakan modal sebagai alat kebutuhan sehari-hari.. ${ }^{27}$

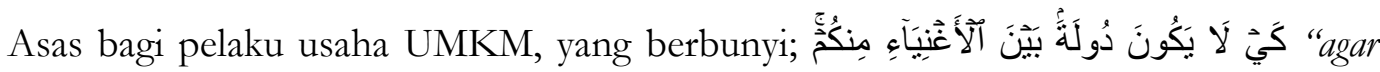
supaya harta tidak berputar diantara orang-orang kaya diantara kamu” (Q.S. Al Hasyr: 7). Oleh karena itu, BMT yang sumber dananya dari masyarakat, maka rakyat miskin itu harus diperhatikan, karena mengingat prinsip-prinsip/nilai-nilai keislaman, yaitu; untuk mensejahterakan masyarakat golongan kebawah. Adanya lembaga keuangan yang menerapkan prinsip tolong-menolong, yang mudah dimengerti bagi masyarakat awam. Maka tidak memungkinkan praktek rentenir akan hilang tersendirinya yang sudah menjadikan kebiasaan ditengah-tengah masyarakat.

\section{Metode Penelitian}

Metodologi yang diapakai dalam penelitian ini adalah deskriptif dengan pendekatan kualitatif. Cara yang peneliti dengan kadar kajian serta analisis untuk memahami dari perkara, peristiwa dan keadaan yang terjadi dilapangan. ${ }^{29}$ Maka dari itu, yang didapatkan dari lapangan, adalah hasil murni yang didapatkan dari dokumentasi kegiatan serta penjelasan pihak BMT NU Cabang Pasean Pamekasan dalam menyalurkan pembiayaan UMKM serta monitoring pengelolaan keuangan UMKM .

BMT NU Cabang Pasean Pamekasan menjadi tempat penelitian dengan cara mempertimbangkan agar penelitian ini dapat digunakan sebagai acuan perbaikan kebiasaan masyarakat didalam melakukan pembiayaan. Hasil penelitian mampu menjadi masukan kepada semua masyarakat khususnya di desa Pasean Pamekasan ke depannya untuk mengurangi praktek pinjaman ke rentenir. Informan dalam penelitian ini yaitu; pegawai, anggota dan tokoh masyarakat sekitar.

\footnotetext{
${ }^{25}$ Muhammad Syafii Antonio, Bank Syariab: Dari Teori Ke Praktik (Jakarta: Gema Insani Press, 2001). h.79.

${ }^{26}$ Neni sri imaniyati, Aspek-Aspek Hukum Bmt (Baitul Maal Wat Tamwil) (Bandung: pt citra citra aditya bakti, 2010). h. 126.

${ }^{27}$ M. Umer Chapra, Sistem Moneter Islam (Jakarta: Gema Insani Press, 2000). h.9.

${ }^{28}$ al-Qur'an, 59: 7.

${ }^{29}$ Supardi, Metodologi Penelitian Ekonomi Bisnis (Yogyakarta: UII Press, 2005). h. 28.
} 
Data yang penulis dapatkan dari lapangan dikaji kembali sampai menemukan data yang valid, setelah itu data yang valid tersebut diproses sesuai dengan sistem yang ada: pertama, Reduksi data yaitu; proses memilah-milah data yang vaild, penyederhanaan data, pengabstrakkan dan transformasi data mentah atau data kasar yang muncul dari catatancatatan tertulis dilapangan. Kedua, Data display adala pengambilan informasi yang disusun ke dalam suatu bentuk yang sistematis. Sehingga menjadi lebih selektif dan sederhana serta memberikan kemungkinan adanya penarikan kesimpulan data dan pengambilan tindakan. Ketiga, adalah pemberian kesimpulan yang menjadi tahap akhir dalam proses analisa data. Pada bagian ini penyusun mengutarakan kesimpulan dari data-data yang telah diperoleh dari observasi, interview, dan dokumentasi.

\section{Hasil Penelitian}

1. Jumlah UMKM Tahun 2020 di Pamekasan.

\section{Gambar 3. Jumlah UMKM di Pamekasan}

\begin{tabular}{cccc}
\hline \hline Bakorwil & UMK & UMB & Jumlah \\
\hline (1) & $(2)$ & $(3)$ & $(4)$ \\
\hline Pamekasan & 108,022 & 445 & 108,467 \\
& $(99,59)$ & $(0,41)$ & $(100,00)$ \\
\hline
\end{tabular}

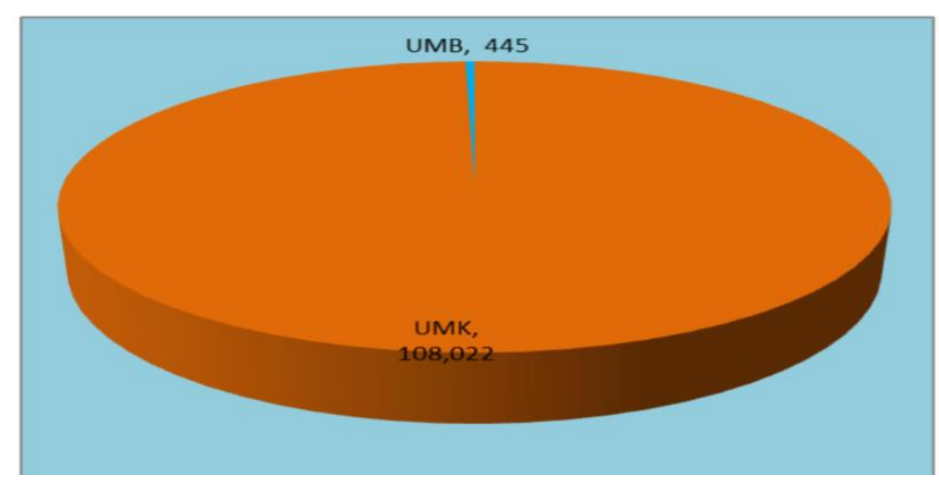

Sumber : BPS Pamekasan, 2020

Perekonomian di Indonesia telah menurun disebabkan adanya virus corona (covid 19), diantara pelaku usaha mikro, kecil. Dukungan Pemerintah terhadap pelaku usaha UMKM industri sebesar Rp 70,1 triliun, pelaku dunia usaha sebesar Rp 150 triliun. Pemerintah menganspirasi adanya pelaku usaha UMKM, karena pelaku usaha UMKM memberikan sumbangan terhadap pemerintah $60,3 \%$ dari total produk domestik bruto (PDB) Indonesia. Oleh karena itu, pelaku usaha UMKM akan menyerap 97\% tenaga kerja sebesar 99\% dari total lapangan pekerjaan. Pada tahun 2018, UMKM tercatat sebanyak 64,19 juta unit. Oleh sebab itu, kementerian koperasi dan UMK berkomitmen hingga tahun 2020 menargetkan10 juta UMKM untuk masuk ke ekosistem digital. ${ }^{30}$

Jumlah UMKM di Indonesia termasuk perhitungan besar, begitupun salah satu kabupaten di Madura yaitu, Pamekasan. Usaha Menengah Besar (UMB) di Pamekasan

\footnotetext{
30"Pemerintah-Beri-Stimulus-Berapa-Jumlah-Umkm-Di-Indonesia,"

Ttps://Databoks.Katadata.Co.Id/Datapublish/2020/04/08/. diakses pada 9 Juli 2020.
} 
hanya 0,41\% yaitu, 445 dan Usaha Mikro Kecil (UMK) mendominasi 99,59\% yaitu, 108.022. Secara rinci, pengkategoriannya yaitu sebagai berikut :

Gamabr 4. Pengkategorian UMKM di Pamekasan

\begin{tabular}{|c|c|c|}
\hline Lapangan Usaha & Jumlah Usaha & $\begin{array}{c}\text { Distribusi } \\
(\%)\end{array}$ \\
\hline (1) & (2) & (3) \\
\hline B.Pertambangan dan penggalian & 928 & 0.86 \\
\hline C. Industri Pengolahan & 48,723 & 44.92 \\
\hline D. Pengadaan Listrik, Gas, Uap/Air Panas dan Udara Dingin & 53 & 0.05 \\
\hline $\begin{array}{l}\text { E. Pengelolaan Air, Pengelolaan Air Limbah, Pengelolaan dan Daur } \\
\text { Ulang Sampah, dan Aktivitas Remediasi }\end{array}$ & 226 & 0.21 \\
\hline F. Konstruksi & 1,962 & 1.81 \\
\hline $\begin{array}{l}\text { G. Perdagangan Besar Dan Eceran; Reparasi Dan Perawatan Mobil } \\
\text { Dan Sepeda Motor }\end{array}$ & 36,077 & 33.26 \\
\hline H. Pengangkutan dan pergudangan & 4,025 & 3.71 \\
\hline I. Penyediaan Akomodasi Dan Penyediaan Makan Minum & 7,448 & 6.87 \\
\hline J. Informasi Dan Komunikasi & 993 & 0.92 \\
\hline K. Aktivitas Keuangan Dan Asuransi & 157 & 0.14 \\
\hline L. Real Estat & 131 & 0.12 \\
\hline M. Aktivitas Profesional, IImiah Dan Teknis & 121 & 0.11 \\
\hline $\begin{array}{l}\text { N. Aktivitas Penyewaan dan Sewa Guna Usaha Tanpa Hak Opsi, } \\
\text { Ketenagakerjaan, Agen Perjalanan dan Penunjang Usaha Lainnya }\end{array}$ & 626 & 0.58 \\
\hline P. Pendidikan & 3,192 & 2.94 \\
\hline Q. Aktivitas Kesehatan Manusia Dan Aktivitas Sosial & 962 & 0.89 \\
\hline R. Kesenian, Hiburan Dan Rekreasi & 202 & 0.19 \\
\hline S. Aktivitas Jasa Lainnya & 2,641 & 2.43 \\
\hline $\begin{array}{l}\text { U. Kegiatan Badan Internasional dan Badan Ekstra Internasional } \\
\text { Lainnya }\end{array}$ & 0 & - \\
\hline
\end{tabular}

Sumber : BPS Pamekasan, 2020

Gambar di atas akan menjelaskan pemberian usaha/perusahaan berdasarkan lapangan usaha, diutamakan oleh lapangan usaha industri pengolahan sebanyak 48.723 usaha/perusahaan atau 44,92 \% serta dari semua usaha/perusahaan yang ada di Pamekasan. Kemudian bagi pelaku usaha perdagangan besar dan eceran sebesar 33,26 $\%$, penyediaan akomodasi serta penyediaan makan minum sebesar $6,87 \%$. Selebihnya $14,95 \%$ merupakan lapangan usaha lainnya.

2. Peranan Koperasi Simpan Pinjam Pembiayaan Syariah (KSPPS) BMT NU Cabang Pasean Pamekasan Terhadap Usaha Mikro Kecil Menengah (UMKM)

a. BMT NU sebagai penyedia modal usaha melalui pembiayaan UMKM

Lembaga keuangan mikro Syariah yang sebagai lembaga Baitul Mal Wat Tamwil (BMT) pernah mengalami perkembangan yang pasang surut. Jumlah BMT Pada pertengahan tahun 1990-an tercatat 3.000 unit. Namun, dibulan Desember tahun 2020, banyak BMT yang masih aktif diperkirakan mencapai 4.500 unit.

Upaya yang dilakukan oleh pemerintah dalam mengembangkan aset UMKM lebih baik, yaitu dengan memberikan asimulasi/pelatihan terhadap perkembangan usaha UMKM tersebut. Dengan praktek memudahkan penyaluran dana kepada pelaku usaha UMKM, namun tidak menghilangkan prinsip-prinsip Syariah didasari dengan beberapa akad seperti, akad mudharabah (bagi hasil), murabahah (jual beli). Jika persoalan tersebut jalan maka, akan sejahtera baik dari pemerintah pusat, maupun sampai rakyat kecil. 


\section{Gambar 5. Kategori Sampel Berdasarkan Pendidikan ${ }^{31}$}

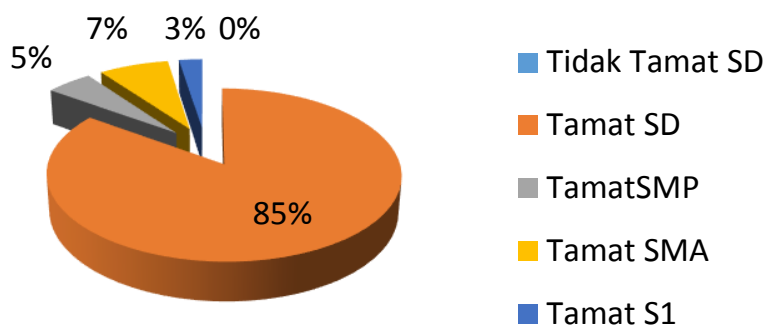

Gambar 6. Kategori Sampel Berdasarkan Pekerjaan ${ }^{32}$

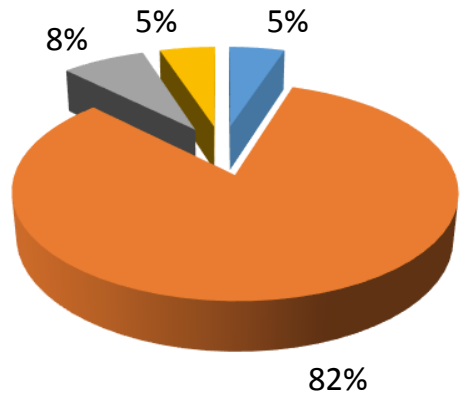

Total UMKM yang mengambil pembiayaan di BMT NU cabang Pasean Pamekasan berjumlah 1452. Sedangkan total UMKM didaerah Pamekasan sebagaimana di BMT NU cabang Pasean Pamekasan tahun 2020 di Kabupaten Pamekasan berjumlah 108.467 UMKM.

Jadi dari sekian banyak UMKM yang disentuh oleh BMT NU Pamekasan sekitar 0,01\% mengingat di Daerah Kabupaten Pamekasan di dominasi oleh Perbankan Konvensional. Sedangkan untuk Perbankan Syariah yang ada di daerah Pamekasan yaitu Bank Mandiri Syariah, BRI Syariah, BMT, dan BPRS, dari lembaga perbankan Syariah tersebut mengeluarkan pembiayaannya kepada UMKM, kecuali Bank Mandiri Syariah Pamekasan.

Sedangkan karakteristik nasabah pembiayaan UMKM dari BMT NU Cabang Pasean Pamekasan menurut jenis kelamin, faktor usia, status pernikahan, jenjang pendidikan, dan lebih senior dalam pengelolaan usaha tersebut berdasarkan keterangan pihak BMT yaitu sebagai berikut:

1) Pelaku UMKM dalam mengambil produk pembiayaan, pria sebanyak $83 \%$ dan $17 \%$ adalah wanita.

2) Komponen Pelaku UMKM tercatat paling banyak antara usia 41-50 tahun, adalah $42,72 \%$, dari usia $31-40$ tahun, adalah $31,07 \%,>60$ tahun adalah $3,88 \%$.

\footnotetext{
${ }^{31}$ Bpk. Syaiful Bahri, Wawanaca, BMT Nu Cabang Pasean Pamekasa. 9 Agustus 2020.

32 Bpk. Syaiful Bahri, Wawanaca, BMT Nu Cabang Pasean Pamekasa. 9 Agustus 2020.
} 
3) Pelaku UMKM yang sudah berkeluarga, sebanyak $90,29 \%$ sudah menikah, adapun, orang belum menikah sebesar 6,79\%, duda/janda sebanyak 2,92\%.

4) Jenjang pendidikan keseluruhan bagi pelaku usaha pembiayaan UMKM, diploma 3,88\%, sarjana, 4,83\%, SMA, 57,28\%, SMP 28,16\%, SD 5,83\%.

5) Tingkat pengalaman bagi pelaku usaha UMKM, dihitung sejak 1-5 tahun, adalah sebanyak 50,46\%, dari 5-10 adalah sebanyak 40,78\%, serta sebanyak 4,86\% dihitung dari 10-15 tahun, kurang dari 1 tahun adalah sebanyak 0,9\%.

Berikutnya kategori penerima pembiayaan UMKM, BMT NU cabang Pasean Pamekasan, berdasarkan jenis usaha, lokasi, dan kepemilikan usaha tersebut yaitu:

1) Jenis usaha dari keseluruhan nasabah, pertama, perdagangan sebanyak 49,51\%, kedua, bidang jasa memiliki 20,39\%, ketiga, kerajinan rumah tangga sebanyak 18,45\%, keempat, pertanian sebanyak 9,71\%, kelima, perikanan sebanyak $1,94 \%$.

2) Lokasi usaha UMKM dilihat dari kepemilikan tempat sendiri sebanyak $85,44 \%$ dan penyewaan tempat usaha sebanyak $14,56 \%$. Maka hasil tersebut menujukkan bahwa lokasi yang dimiliki sendiri sebanyak 97,08\% dan yang melakukan sinergitas dengan orang lain sebanyak 2,92\%.

3) Bagi pemula usaha UMKM dalam melakukan pembiayaan di lembaga BMT NU Cabang Pasean Pamekasan dengan jumlah berkisar Rp1.000.000,0 Rp5.000.000,00. Adalah sebanyak 49,51\%, pemula usaha yang memiliki Rp5.000.000,00- Rp10.000.000,00 adalah sebanyak 17,48\%, dan pelaku usaha memiliki modal awal lebih besar dari Rp15.000.000,00 adalah sebanyak $6.80 \%$

3. BMT NU Melakukan Pendampingan Usaha Dan Pelatihan Manajemen Keuangan

Permasalah yang ada di daerah pamekasan yaitu karena pelaku usaha UMKM kurang diperhatikan dari segi kualitas SDM, maka dalam mengatur pengeluaran dan pemasukan harga sulit dijangkau, apalagi dalam pemasaran product masih jauh dari perkembangan zaman, dimana etika bisnis ekonomi islam yang sudah mencapai 5.0 yang berubah dari sebelumnya 4.0. maka solusinya pemerintah harus ikut campur tangan dalam memajukan usaha UMKM dengan memoderanisasi tingkat pemasarannya. Selain itu juga lembaga keuangan Syariah harus memberikan training terhadap pemula usaha UMKM atau dengan melakukan sosialisasi tiap bulannya.

Pengaturan keuangan dari hasil penjualan tidak hanya sekedar memutar di daerah tersebut. Maka dengan pengetahuan yang sudah dibekali sebelumnya dapat mengembangkan aset usahanya di berbagai daerah. Akan tetapi dalam setiap usaha mesti banyak risiko yang perlu dihadapi msialnya; dari penghasilan seringkali terjadi ketidak seimbangan antara pemasukan dan pengeluaran, sehingga bagi pelaku usaha UMKM harus mempunyai buku catatan terkait pengeluaran dan pemasukan, agar terhidar yang namanya usaha gulungpikar yaitu; bangkrut disebabkan modal usaha yang telah habis yang tidak diketahui dibelanjakan kemana?.

4. Relasi BMT NU Cabang Pasean Pamekasan dan UMKM dalam peranannya

Hubungan UMKM dengan suatu lembaga BMT NU akan menjadikan akar dalam memajukan perekonomian di Pamekasan khusunya, terlihat masyarakat pamekasan yang cenderung tidak pergi dari daerahnya, mereka tidak suka merantau ke negara lain 
karena mereka paham dengan kondisi di daerah mereka yang artinya mereka melakukan hubungan kepada lembaga perbankan syariah untuk meminta bantuan modal di dalam membuka sebuah usaha. masyarakat yang membuka usaha akan meningkat pendapatannya dan kesejahteraanya dan tentu secara langsung akan mengurangi kemiskinan, serta menghapus praktek rentenir.

Di sinilah peran masyarakat UMKM yang telah mendapat pelatihan dan edukasi keuangan untuk mensosialisasikan keapada masyarakat biasa tersebut. Karena terkadang orang punya keahlian tapi orang tersebut takut untuk berwirausaha/menjadi pelaku UMKM, karena mengingat dengan risiko yang tinggi maka mereka takut untuk berbuat seperti itu. Dengan demikian, BMT harus bisa memberikan masukan atau memberikan solusi kepada masyarakat, sehingga masyarakat tidak takut lagi di dalam melakukan usaha UMKM tersebut. Semakin banyak masyarakat yang terjun kedunia usaha UMKM maka semakin baik pula dalam meningkatkan pendapatan mereka terutama pendapatan daerah pamekasan khususnya dan pemerintah pusat pada umumnya.

UMKM yang ada di Pamekasan diatur dalam undang-undang nomer 8 tahun 2008 tentang pemberian bantuan kepada pelaku usaha UMKM yang dijadikan usaha untuk mencari rezeki dengan memberikan kebutuhan keluarga. Akan tetapi, adanya UMKM akan memberikan lapangan pekerjaan bagi masyarakat yang mempunyai bakat, tapi tidak mau usaha, disebabkan takut terhadap risikonya. Maka ia memilih mau bekerjasama dengna orang lain. ${ }^{33}$

\section{Penutup}

Kesimpulan peneliti bahwa, hubungan BMT NU kepada pelaku usaha UMKM telah berperan dalam mensejahterakan masyarakat serta mengurangi tingkat kemiskinan dan menghapus praktek rentenir. Hal ini dibuktikan bahwa dari sekian banyaknya pelaku usaha UMKM yang telah mengajukan pembiayaan di BMT NU sebelum mereka mengajukan pembiayaan mereka kekurangan uang untuk dijadikan usaha pedagang kebutuhan primer.

Sedangkan dilihat Peran BMT terhadap UMKM berupa pembiayaan UMKM Sesuai dengan data BPS Pamekasan tahun 2020 berjumlah 108.467 UMKM. Sedangkan UMKM yang mengambil pembiayaan Lembaga Keuangan Syariah yaitu di BMT NU Cabang Pasean Pamekasan sekitar 1452. Dalam artian di daerah Pamekasan hanya 0,01\% UMKM yang menjadi nasabah Lembaga Keuangan Syariah yaitu BMT NU Cabang Pasean Pamekasan. Selain itu BMT juga sebagai pendamping usaha dan juga pernah mengadakan pelatihan manajemen keuangan, tapi program ini tidak efektif karena UMKM yang tidak proaktif.

\section{Daftar Pustaka}

Adiwarman Karim. Bank Islam Analisis Fiqib Dan Keuangan. Jakarta: RajaGrafindo Persada, 2006.

Ahmad Ifham Sholihin. Ini Lho, Bank Syariah. Jakarta: Hamdalah, 2008.

\footnotetext{
${ }^{33}$ Muhammad, Lembaga Kenangan Mikro Syariah (Yogyakarta: Graha Ilmu, 2009). h.41.
} 
Amin Aziz. Kegigihan Sang Perintis. Jakarta: MAA Institute, 2007.

Andri Soemitra. Bank Dan Lembaga Kenangan Syariah. Jakarta: Kencana Prenada Media Group, 2010.

Ascarya. Akad \& Produk Bank Syariah. Jakarta: PT RajaGrafindo Persada, 2008.

Aswandi S. "Umkm Di Tengah Krisis Ekonomi-Perannya Besar, Minim Perhatian Pemerintah." bttp:/ / www.sme-center.com (2007).

Awalil Rizky. BMT Fakta Dan Prospek Baitul Maal Wa Tamwil. yogyakarta: Kreasi Wacana, 2007.

Braman Setyo. "Deputi Bidang Pembiayaan Kemenkop UKM." Https:/ / Investor.Id/Business/Pamekasan-Kabupaten-Pertama-Komit-Kembangkan-KoperasiSyari'ah.

Friska Yolandha. "Pembiayaan Mikro Perbankan Syariah 70 Persen." Https:// wmw.Republika.Co.Id/Berita/Ekonomi/Syariah-Ekonomi/12/10/25/Mcg98qPembiayaan-Mikro-Perbankan-Syariah-70-Persen.

Hidayat, Solikhul, "Persepsi Masyarakat Terhadap Baitul Maal Wat Tamwil (Bmt) DalamPemberdayaan Ekonomi Masyarakat", Al-Uqud: Journal of Islamic Economics Volume 2 Nomor 2, Juli (2018): 199.

Jamal Lulail Yunus. Managemen Bank Syariah "Mikro. Malang: UIN Malang Press, 2009.

Koran Madura. "Data Pelaku UMKM." Http:/ / mww.Koranmadura.Com/2018/12/TernyataData-Pelaku-Umkm-Di-Pamekasan/.

Lubis, Fauzi Arif. "Peranan BMT Dalam Pemberdayaan Ekonomi Nasabah Di Kecamatan Berastagi-Kabanjahe Kabupaten Karo (Studi Kasus Bmt Mitra Simalem Al-Karomah )" (n.d.).

M. Nur Rianto Al-Arif. Dasar-Dasar Ekonomi Islam. Solo: PT Era Audicitra Intermedia, 2011.

M. Umer Chapra. Sistem Moneter Islam. Jakarta: Gema Insani Press, 2000.

Makhalul Ilmi. Teori Dan Praktek Lembaga Mikro Kenangan Syariah. Yogyakarta: UII Press, 2002.

Muhammad. Lembaga Kenangan Mikro Syariah. Yogyakarta: Graha Ilmu, 2009.

Muhammad Ridwan. Manajemen Bank Syariah. yogyakarta: UPP AMP YKPN, 2003.

Muhammad Syafii Antonio. Bank Syariah: Dari Teori Ke Praktik. Jakarta: Gema Insani Press, 2001.

Neni sri imaniyati. Aspek-Aspek Hukum Bmt (Baitul Maal Wat Tamwil). Bandung: pt citra citra aditya bakti, 2010 .

Novita Dewi Masyitoh. “Analisis Normatif Undang-Undang Nomor 1 Tahun 2013 Tentang Lembaga Keuangan Mikro (LKM) Atas Status Badan Hukum Dan Pengawasan Baitul Maal Wat Tamwil (BMT).” Jurnal Economica Vol.V (2014): 18.

Nurul Huda, Mohamad Heykal. Lembaga Kenangan Islam Tinjanan Teoritis Dan Praktis. Jakarta: PT. Fajar Interpratama Mandiri, 2013.

Prastiawati, Fitriani, Emile Satia Darma, Prodi Akuntansi, Universitas Muhammadiyah, Jln 
Lingkar Selatan, and D I Yogyakarta. "Peran Pembiayaan Baitul Maal Wat Tamwil Terhadap Perkembangan Usaha Dan Peningkatan Kesejahteraan Anggotanya Dari Sektor Mikro Pedagang Pasar Tradisional” 17, no. 2 (2016): 197-208.

Saputra, Dimas. "Respons Masyarakat Terhadap Produk Pembiayaan BMT Di Kartasura" 1, no. 2 (2017).

Supardi. Metodologi Penelitian Ekonomi Bisnis. Yogyakarta: UII Press, 2005.

Teten Masduki. "Yang Sebelumnya Jumlah Pelaku Umkm Di Tahun 2018 Diprediksi Mencapai 58,97 Juta Orang,Sekarang Menggagas Program Bertajuk 8 Juta UMKM Go Online." Https://wnw.Cnnindonesia.Com/Ekonomi/20171115161037-78255819/Kemenkop-Ukm-379-Juta-Umkm-Sudab-Go.

"LPS Bagi BMT Sebagai Bentuk Perlindungan Hukum." Http:// www.Academia.Edu/5380514/Urgensi.

"Pemerintah-Beri-Stimulus-Berapa-Jumlah-Umkm-Di-Indonesia." Ttps://Databoks.Katadata.Co.Id/Datapublish/2020/04/08/. 